\title{
Iodination of Phenols in Water using Easy to Handle Amine-Iodine Complexes
}

\author{
Lívia C. R. M. da Frota, Raquel C. P. Canavez, Sara L. da Silva Gomes, \\ Paulo R. R. Costa and Alcides J. M. da Silva* \\ Núcleo de Pesquisas de Produtos Naturais, Universidade Federal do Rio de Janeiro, \\ Centro de Ciências da Saúde, Bloco H, Ilha do Fundão, 21941-540 Rio de Janeiro-RJ, Brazil
}

\begin{abstract}
A reação entre o iodo e a $N$-metil-piperazina ou a tiomorfolina em água, na presença de KI, levou a formação de complexos amina-iodo estáveis e de fácil manipulação, tal qual o complexo morfolina-iodo, previamente descrito na literatura. Entretanto, o complexo formado entre o iodo e a $N, N$-tetrametiletilenodiamina mostrou-se pouco estável, enquanto que nenhum complexo foi isolado quando a piperidina foi usada como base. Estes resultados mostram que a presença do segundo heteroátomo na estrutura das aminas é fundamental para a formação e estabilidade desses complexos. Neste trabalho descrevemos, pela primeira vez, o emprego dos complexos morfolina-iodo, $N$-metil-piperazina-iodo e tiomorfolina-iodo como agentes de iodação de vários fenóis substituídos, conduzindo a uma série de produtos iodados em rendimentos variando de bons a excelentes.
\end{abstract}

The reaction between iodo and $N$-methyl-piperazine or thiomorpholine in water, in the presence of KI, led to the formation of stable and easy to handle amine-iodine complexes, as the complex morpholine-iodo previously reported in the literature. However, the complex obtained using $N, N$ tetrametylethylenediamine proved less stable, while no complex was formed when piperidine was used as base. These results show that the presence of a second heteroatom in the structure of amines is of fundamental importance for the formation and stability of these complexes. In this work we describe, for the first time, the use of complexes morpholine-iodo, $N$-methyl-piperazine-iodo and thiomorpholine-iodo as iodinating reagents of several substituted phenols, leading to iodinated products in good to excellent yields.

Keywords: iodophenols, amine-iodine complexes, aromatic iodination, iodinating reagents, ortho-iodophenols

\section{Introduction}

Aryl iodophenols and other aryl iodides are versatile intermediates in organic synthesis, being used as precursors of new carbon-carbon bonds. These compounds can be used as source of aryl organometalic species as well as substrates for these species in cross-coupling reactions. ${ }^{1-9}$ In particular, the palladium catalyzed oxyarylation of chromens by orthoiodophenols have been used to synthesize pterocarpans and its derivatives. ${ }^{10,11}$ On the other hand, coumarins were formed through a tandem Heck-lactonization reaction when these species were allowed to react with enoates and cinnamates. ${ }^{12,13}$

Continuing interest of organic chemists in iodination reactions are due to the versatility of iodinated compounds

*e-mail: alcides@nppn.ufrj.br,prrcosta@ism.com.br as building blocks in a variety of synthetic transformations in medicinal chemistry, as well as in the biomedical sciences as imaging agents in non-invasive medical diagnostic techniques due to the possible release of the long-lived radioactive ${ }^{129} \mathrm{I}$ isotope. ${ }^{14-18}$ In the 1950's the hormone thyroxine and its analogues were prepared as radioiodinated photoprobes. ${ }^{19-23}$

A broad range of procedures are described in the literature for the iodination of phenols, involving the use of NIS, ICl, $\mathrm{I}_{2}$ and iodides salts in the presence of an oxidant, in acid or basic conditions. ${ }^{24-34}$ Recently, Esteves and Mattos ${ }^{35}$ described the scope of the triiodoisocyanuric (TICA) acid as iodinating agent. The reaction of TICA with activated arenes in acetonitrile led to an efficient and highly regioselective formation of the corresponding iodoarenes. Aniline and phenol were monoiodinated regioselectively using $\mathrm{MeOH}$ and $\mathrm{CH}_{2} \mathrm{Cl}_{2}$ as solvents, respectively. 
Amines can also be used to increase the reactivity of $\mathrm{I}_{2}$ and Hinman and Giza ${ }^{36}$ used iodine in the presence of morpholine as iodinating agent to synthesize thyroxine analogs from 3-carbethoxy-5-hydroxy-2methylbenzofuran. Iodine in the presence of amines react readily with benzophenone, cinnamates and chalcones leading to $\alpha, \beta$-diamino-benzylacetophenones and $\alpha, \beta$-diamino-benzylacetones derivatives ${ }^{37}$ While in most cases complexes of $\mathrm{I}_{2}$ with amines are generated and used in situ, ${ }^{13,14}$ a stable and easily to handle complex 1a (Figure 1) was prepared by Rice ${ }^{38}$ just mixing of morpholine, KI and $\mathrm{I}_{2}$ in water. Recently Perez et al..$^{39}$ described the use of this complex as iodinating reagent to prepare 2-hydroxy-3iodo-naphthoquinone from lawsone in $87 \%$ yield, but did not evaluate the scope of this new iodinating agent using other phenols as substrates.

In this paper we describe the synthesis of new amineiodine complexes (1)-d), structurally related to complex $\mathbf{1 a}$. The scope of these complexes (1a-d) as iodinating agents was evaluated for the first time using a series of phenols (2-5) as substrates (Figure 1).

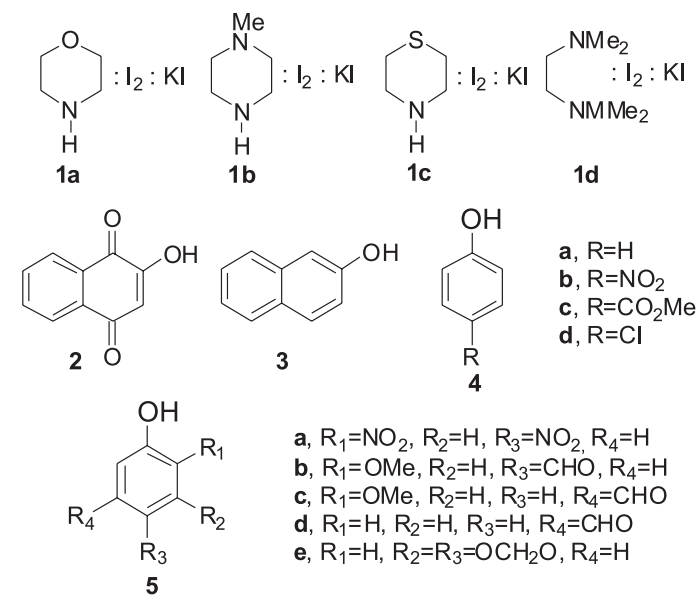

Figure 1. Iodine-amine complexes and phenols studied in this work.

\section{Results and Discussion}

A series of secondary amines $(\mathbf{7 , 8}$ and $\mathbf{1 0})$ and a tertiary amine (9) were allowed to react with $I_{2}$ in water in the presence of KI, under the conditions described by Rice ${ }^{38}$ to prepare 1a. Stable complexes (1) and $\mathbf{1 c}$ ) were formed when $N$-methyl-piperazine (7) and thiomorpholine (8) were used (Scheme 1). In contrast, complex 1d, obtained from $N, N$-tetrametylethylenediamine (9), was unstable and completely decomposes at room temperature after $1 \mathrm{~h}$. In contrast, no complex could be isolated from the reaction of $\mathrm{I}_{2}$ with piperidine (10).

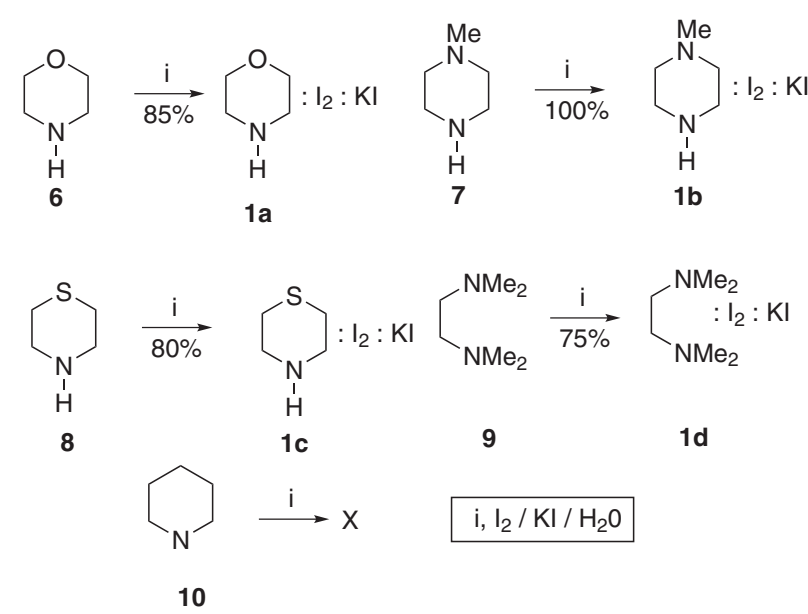

Scheme 1. Synthesis of complexes 1a-d.

Complexes 1a, 1b, 1c and $\mathbf{1 d}$ were used as iodinating agents of phenols 2-5. The reactions are shown in Schemes 2, 3, 4 and 5 and yields obtained are shown in Table 1.<smiles>O=C1C=C(O)C(=O)c2ccccc2C1=O</smiles>

Scheme 2. Iodination of $\mathbf{2}$ by complexes $\mathbf{1 a - d}$.

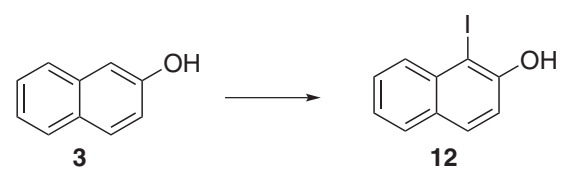

Scheme 3. Iodination of $\mathbf{3}$ by complexes 1a-d.<smiles>Oc1ccc(Br)cc1</smiles>

4

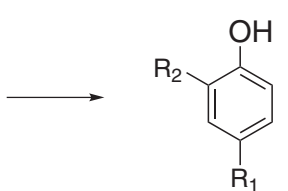

13
a, $\mathrm{R}_{1}=\mathrm{H} ; \mathbf{b}, \mathrm{R}_{1}=\mathrm{NO}_{2}$
c, $\mathrm{R}_{1}=\mathrm{CO}_{2} \mathrm{Me} ; \mathrm{d}, \mathrm{R}_{1}=\mathrm{Cl}$
a, $R_{1}=I, R_{2}=H ; b, R_{1}=N_{2}, R_{2}=l$;
c, $\mathrm{R}_{1}=\mathrm{CO}_{2} \mathrm{Me}, \mathrm{R}_{2}=\mathrm{I} ; \mathbf{d}, \mathrm{R}^{1}=\mathrm{Cl}, \mathrm{R}_{2}=\mathrm{I}$

Scheme 4. Iodination of $\mathbf{4 a - d}$ by complexes 1a-d.

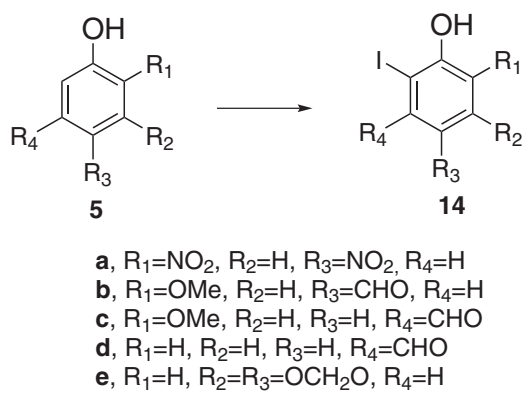

Scheme 5. Iodination of $\mathbf{5 a - e}$ by complexes 1a-d. 
The reaction between complexes 1a-d (1.2 eq) with lawsone 2 (entries 1-4) gave 3-iodolawsone (11) in excellent yields, $87 \%, 90 \%, 80 \%, 80 \%$, respectively. Contrasting to the use of some iodinating agents, ${ }^{24,40-42}$ which in general lead to products of poly-iodination, phenol (4a) furnished para-iodophenol 13a ${ }^{24}$ in good yields by reaction with complexes $\mathbf{1 a}, \mathbf{1 b}$ and $\mathbf{1 c}$ (entries 5-7). We also examined the iodination of the phenols $\mathbf{4 b}$, $\mathbf{4 c}$ and $\mathbf{4 d}$, bearing electron withdrawing substituents at the para position $\left(\mathrm{NO}_{2}, \mathrm{CO}_{2} \mathrm{CH}_{3}\right.$ and $\mathrm{Cl}$ ) (entries 8-16) and the desired products $\mathbf{1 3 b},{ }^{24} \mathbf{1 3}^{24}$ and $\mathbf{1 3} \mathbf{d}^{24}$ were obtained in good yields by using complexes 1a-d. However, only starting material was observed when highly deactivated phenol 5a was allowed to react with complex 1a (entry 17).

Using the complexes $\mathbf{1 a}$ or $\mathbf{1 b}$, vanillin $\mathbf{5 b}$ and isovanillin 5c (entries 18-21), having activating and deactivating groups at the aromatic ring, also led to the corresponding ortho-iodophenol derivatives $\mathbf{1 4} \mathbf{b}^{27}$ and $\mathbf{1 4 c},^{28}$ although the para position in $\mathbf{2 h}$ is not substituted. A mixture of non-identified products was obtained when the $m$-hydroxy-benzaldehyde (5d) was treated with the complex 1a (entry 22). Unfortunately, sesamol 5e, a very activated phenol, furnished only products of degradation when allowed to react with $\mathbf{1 a}$ (entry 23). $\alpha$-Naphthol 3 led to $\mathbf{1 2}$ in $60 \%$ and $63 \%$ yield, respectively (entries 24-25), by reaction with complexes $\mathbf{1 a}$ or $\mathbf{1 b} .^{24}$

Several groups have studied the structure of complexes formed between halogens and interhalogens with $n$-donors. ${ }^{43-46}$ According to Manoharan and Ananthavel, ${ }^{47}$ a suitable interaction exist between $\sigma^{*}$-orbital in the interhalogen (LUMO) and lone electron pair of donor (HOMO). The greater the overlap and/or the smaller energy difference between the HOMO of the donor and the LUMO of acceptor, the larger the stabilization energy $(\Delta)$, and the greater the extent of mixing, which causes more charge transfer from the donor to the acceptor. ${ }^{48-52}$

Amine-iodine complexes have been studied by UV and IR spectroscopy and a dipolar structure has been suggested (Figure 2) ${ }^{53,54}$ Based on our results, the presence of the second hetero-atom in the structure of $\mathbf{1 a}, \mathbf{1 b}$ and $\mathbf{1 c}$, respectively, is essential for the stability of the complexes, but do not influence the reactivity, and consequently the yields of products. Studies toward the structural elucidation of these complexes are underway in our laboratories.

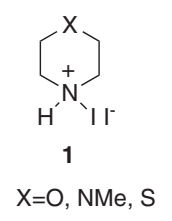

Figure 2. Structure of 1a, 1b and 1c
Table 1. Synthesis of the iodophenols using the complexes 1a-d

\begin{tabular}{|c|c|c|c|c|}
\hline Entry & $\mathrm{ArOH}$ & Complex* & Product & Yield / \% \\
\hline 1 & 2 & $1 \mathrm{a}$ & $11^{* *}$ & 87 \\
\hline 2 & 2 & $1 b$ & 11 & 90 \\
\hline 3 & 2 & $1 \mathrm{c}$ & 11 & 80 \\
\hline 4 & 2 & $1 d$ & 11 & 80 \\
\hline 5 & $4 a$ & $1 \mathrm{a}$ & $13 \mathrm{a}$ & 92 \\
\hline 6 & $4 a$ & $1 b$ & $13 \mathrm{a}$ & 70 \\
\hline 7 & $4 a$ & $1 \mathrm{c}$ & $13 \mathrm{a}$ & 77 \\
\hline 8 & $4 b$ & $1 \mathrm{a}$ & $13 b$ & 70 \\
\hline 9 & $4 b$ & $1 b$ & $13 b$ & 70 \\
\hline 10 & $4 c$ & $1 \mathrm{a}$ & $13 \mathrm{c}$ & 95 \\
\hline 11 & $4 c$ & $1 b$ & $13 \mathrm{c}$ & 90 \\
\hline 12 & $4 c$ & $1 \mathrm{c}$ & $13 \mathrm{c}$ & 96 \\
\hline 13 & $4 c$ & $1 \mathrm{~d}$ & $13 \mathrm{c}$ & 80 \\
\hline 14 & $4 d$ & $1 \mathrm{a}$ & $13 d$ & 70 \\
\hline 15 & $4 d$ & $1 b$ & $13 \mathrm{~d}$ & 78 \\
\hline 16 & $4 d$ & $1 \mathrm{c}$ & $13 \mathrm{~d}$ & 65 \\
\hline 17 & $5 \mathrm{a}$ & $1 \mathrm{a}$ & SM & - \\
\hline 18 & $5 b$ & $1 \mathrm{a}$ & $14 \mathrm{~b}$ & 90 \\
\hline 19 & $5 b$ & $1 b$ & $14 \mathrm{~b}$ & 87 \\
\hline 20 & $5 c$ & $1 \mathrm{a}$ & $14 \mathrm{c}$ & 70 \\
\hline 21 & $5 c$ & $1 b$ & $14 \mathrm{c}$ & 87 \\
\hline 22 & $5 \mathrm{~d}$ & $1 \mathrm{a}$ & mixture & - \\
\hline 23 & $5 e$ & $1 \mathrm{a}$ & mixture & - \\
\hline 24 & 3 & $1 \mathrm{a}$ & 12 & 63 \\
\hline 25 & 3 & $1 b$ & 12 & 60 \\
\hline
\end{tabular}

*1.2 equiv. of complexes 1a, $\mathbf{1 b}, \mathbf{1 c}$ or $\mathbf{1 d}$ was used. ** ref. 39

In conclusion, in this paper we report the synthesis of new stable in easy to handle amine-iodine complexes $\mathbf{1 b}$ and $\mathbf{1 c}$ from of $N$-methyl-piparazine (7) and thiomorpholine (8), respectively. These complexes were evaluated for the first time as iodinating reagents of phenols, leading to iodinated products in similar yields to those observed for complex 1a. The soft conditions used make them useful iodinating agents.

\section{Experimental}

\section{General}

Melting points were measured with a Fisher-Johns (Fisher Scientific Co) apparatus. ${ }^{1} \mathrm{H}$ NMR was recorded on a Varian Gemini-200 instrument.

\section{Synthesis of complexes $(\mathbf{1 b}, \mathbf{1 c}$ and $\mathbf{1 d})$}

Typical procedure for $\mathbf{1} \mathbf{b}$ : To a stirred solution $\mathrm{N}$-methyl-piperazine $7(1.0 \mathrm{~g}, 10 \mathrm{mmol})$ in $8.0 \mathrm{~mL}$ of water 
was added dropwise a solution of a mixture of $\mathrm{I}_{2}(2.54 \mathrm{~g}$, $10 \mathrm{mmol}$ ) and $4.7 \mathrm{~g}$ of the $\mathrm{KI}$ in $5.0 \mathrm{~mL}$ of water. Orange-red crystals of $N$-methyl-piperazine iodide (1b) immediately start to precipitate. The solid was filtered off and washed with cold $\mathrm{H}_{2} \mathrm{O}$. The product was dried under vacuum to provide the desired complex $\mathbf{1 b}(3.54 \mathrm{~g}, 100 \%)$.

For complex 1c: to thiomorpholine $8(1.03 \mathrm{~g}, 10 \mathrm{mmol})$; $1 c(2.85 \mathrm{~g}, 80 \%)$.

For complex 1d: to $N, N$-tetrametylethylenediamine 9 (1.16g; $10 \mathrm{mmol}) ; \mathbf{1 d}(2.70 \mathrm{~g}, 75 \%)$.

\section{Synthesis of the compounds 11-14}

Typical procedure for 13c: To a mixture of methyl 4-hydroxybenzoate $4 \mathrm{c}(4.56 \mathrm{~g}, 30 \mathrm{mmol})$ and $\mathrm{K}_{2} \mathrm{CO}_{3}$ $(12.6 \mathrm{~g}, 90 \mathrm{mmol})$ in an erlenmeyer flask was added distilled water $(300 \mathrm{~mL})$. The dark red solution was stirred at room temperature while the complex $\mathbf{1 a}$ or $\mathbf{1 b}$ or $\mathbf{1 c}$ or $\mathbf{1 d}$ $(37.5 \mathrm{mmol})$ or was added in small portions every $15 \mathrm{~min}$ during $2 \mathrm{~h}$. The mixture was cooled in an ice bath and then acidified with $25 \% \mathrm{H}_{3} \mathrm{PO}_{4}$ until the $\mathrm{pH}$ was approximately 2. At this point, the mixture was allowed to age $(24 \mathrm{~h})$ and a bright yellow precipitate was formed. The solid was filtered off and washed with cold $\mathrm{H}_{2} \mathrm{O}$. The product was dried under vacuum to provide the desired methyl-3-iodo4-hydroxybenzoate product 13c (7.92 g, 95\%), or (7.50 $\mathrm{g}, 90 \%)$ or $(7.96 \mathrm{~g}, 96 \%)$ or $(6.67 \mathrm{~g}, 80 \%)$, respectively. mp 156-158 ${ }^{\circ} \mathrm{C}\left(\mathrm{mp} 155-159{ }^{\circ} \mathrm{C}\right) ;{ }^{55} \mathrm{H}$ NMR (200 MHz; $\left.\mathrm{CDCl}_{3}\right) \delta 8.37(1 \mathrm{H}, \mathrm{d}, J 2.0 \mathrm{~Hz}) ; 7.93\left(1 \mathrm{H}, \mathrm{dd}, J_{1} 8.8 \mathrm{~Hz}\right.$; $\left.J_{2} 2.0 \mathrm{~Hz}\right), 7.01(1 \mathrm{H}, \mathrm{d}, J 8.0 \mathrm{~Hz}), 3.97(3 \mathrm{H}, \mathrm{s})$.

11: $\mathrm{mp} 178-180{ }^{\circ} \mathrm{C}\left(\mathrm{mp} 177-179{ }^{\circ} \mathrm{C}\right) ;{ }^{39}{ }^{1} \mathrm{H}$ NMR $(200$ $\left.\mathrm{MHz} ; \mathrm{CDCl}_{3}\right) \delta 8.14(1 \mathrm{H}, \mathrm{dd}, J 8.0$ and $2.0 \mathrm{~Hz}) ; 8.08(1 \mathrm{H}$, $\mathrm{dd}, J 8.0$ and $2.0 \mathrm{~Hz}) ; 7.78(1 \mathrm{H}, \mathrm{td}, J 8.0$ and $2.0 \mathrm{~Hz}) ; 7.74$ (1H, td, J 8.0, $2.0 \mathrm{~Hz}$ ).

12: $\mathrm{mp} 90-92{ }^{\circ} \mathrm{C}\left(\mathrm{mp} 92{ }^{\circ} \mathrm{C}\right) ;{ }^{56}{ }^{1} \mathrm{H}$ NMR $(200 \mathrm{MHz}$; $\left.\mathrm{CDCl}_{3}\right) \delta 7.93(1 \mathrm{H}, \mathrm{d}, J 9 \mathrm{~Hz}) ; 7.73$ (overlapping doublets, $2 \mathrm{H}) ; 7.54(1 \mathrm{H}, \mathrm{t}, J 8 \mathrm{~Hz}) ; 6.90(1 \mathrm{H}, \mathrm{d}, J 8.0 \mathrm{~Hz}) ; 7.38(1 \mathrm{H}$, t, $J 8.0 \mathrm{~Hz}) ; 7.26(1 \mathrm{H}, \mathrm{d}, J 8.0 \mathrm{~Hz})$.

13a: $\mathrm{mp} 90-92{ }^{\circ} \mathrm{C}\left(\mathrm{mp} 89-94{ }^{\circ} \mathrm{C}\right) ;{ }^{101} \mathrm{H}$ NMR $(200 \mathrm{MHz}$; $\left.\mathrm{CDCl}_{3}\right) \delta 7.49(2 \mathrm{H}, \mathrm{d}, J 8.8 \mathrm{~Hz}) ; 6.61(2 \mathrm{H}, \mathrm{d}, J 8.8 \mathrm{~Hz})$.

13b: $\mathrm{mp} 85-87^{\circ} \mathrm{C}\left(\operatorname{mp} 86-87^{\circ} \mathrm{C}\right) ;{ }^{57}{ }^{1} \mathrm{H}$ NMR $(200 \mathrm{MHz}$; $\left.\mathrm{CDCl}_{3}\right) \delta 8.60(1 \mathrm{H}, \mathrm{d}, J 2.0 \mathrm{~Hz}) ; 8.09\left(1 \mathrm{H}, \mathrm{dd}, J_{1} 7.0 \mathrm{~Hz}\right.$; $\left.J_{2} 2.0 \mathrm{~Hz}\right) ; 7.08(1 \mathrm{H}, \mathrm{d}, J 7.0 \mathrm{~Hz})$.

13d: $m p$ 75-77 ${ }^{\circ} \mathrm{C}\left(\mathrm{mp} 78^{\circ} \mathrm{C}\right) ;{ }^{58}{ }^{1} \mathrm{H}$ NMR $(200 \mathrm{MHz}$; $\left.\mathrm{CDCl}_{3}\right) \delta 7.70(1 \mathrm{H}, \mathrm{d}, J 2 \mathrm{~Hz}) ; 7.20\left(1 \mathrm{H}, \mathrm{dd}, J_{1} 8.0 \mathrm{~Hz}\right.$, $\left.J_{2} 2.0 \mathrm{~Hz}\right) ; 6.90(1 \mathrm{H}, \mathrm{d}, J 8 \mathrm{~Hz})$. 14b: $\mathrm{mp} 180-182{ }^{\circ} \mathrm{C}\left(\mathrm{mp} 181-182{ }^{\circ} \mathrm{C}\right) ;{ }^{.9}{ }^{1} \mathrm{H}$ NMR $(200$ $\left.\mathrm{MHz} ; \mathrm{CDCl}_{3}\right) \delta 9.80(1 \mathrm{H}, \mathrm{s}) ; 7.91(1 \mathrm{H}, \mathrm{d}, J 1.8 \mathrm{~Hz}) ; 7.46$ (1H, d, J $1.8 \mathrm{~Hz}) ; 3.96(3 \mathrm{H}, \mathrm{s})$.

14c: $m p 168-170{ }^{\circ} \mathrm{C}\left(\operatorname{mp} 169-171.5^{\circ} \mathrm{C}\right) ;{ }^{24}{ }^{1} \mathrm{H}$ NMR $(200$ $\left.\mathrm{MHz} ; \mathrm{CDCl}_{3}\right) \delta 10.0(1 \mathrm{H}, \mathrm{s}) ; 7.55(1 \mathrm{H}, \mathrm{d}, J 8.4 \mathrm{~Hz}) ; 6.92$ (1H, d, J $8.4 \mathrm{~Hz}) ; 3.99(3 \mathrm{H}, \mathrm{s})$.

\section{Acknowledgments}

Financial supports were provided by CAPES, FAPERJ, CNPq, Group of Oncobiology-UFRJ and FINEP. P.R.R.C., L.C.R.F and S.L.S.G are fellows of CNPq, P.R.R.C. is fellow of FAPERJ.

\section{References}

1. Negishi, E.; Coperet, C.; Ma, S.; Liou, S; Liu, F.; Chem. Rev. 1996, 96, 365.

2. Diederich, F.; Stang, P. J.; Metal Catalysed Cross Coupling Reactions; Wiley-VCH: Weinheim, Germany, 1998.

3. Ziegler, C. B.; Heck, R. F.; J. Org. Chem. 1978, 43, 2941.

4. Beletskaya, I. P.; Cheprakov, A. V.; J. Organomet. Chem. 2004, 689, 4055.

5. Negishi, E., ed.; Handbook of Organopalladium Chemistry for Organic Synthesis, John Wiley: New York, 2002.

6. Negishi, E. I.; Pure Appl. Chem. 1981, 53, 2333.

7. Suzuki,A.; Miyaura, N.; Chem. Rev. 1995, 95, 2457.

8. Snieckus, V; Anctil, E. J. G.; J. Organomet. Chem. 2002 , 653, 150.

9. Beletskaya, I. P.; Cheprakov, A. V.; Chem. Rev. 2000, 100, 3009.

10. Larock, R. C. US pat. 5,721,371 1998.

11. Kiss, L.; Kurtán, T.; Antus, S.; Brunner, H.; ARKIVOC, 2003, 69.

12. Ulgheri, F.; Marchetti,M; Piccolo, O.; J. Org. Chem. 2007, 72, 6056.

13. Fernandes, T. de A.; Carvalho, R. de C. C.; Gonçalves, T. M. D.; da Silva, A. J. M.; Costa, P. R. R.; Tetrahedron Lett. 2008, 49, 3322.

14. Tadashi Kometani, T; Watt, D. S.; J. Org. Chem. 1985, 50, 5384.

15. Seevers, R. H.; Counsell, R. E.; Chem. Rev. 1982, 82, 575.

16. Bayley, H.; Knowles, J. R.; Methods Enzymol. 1977, 46, 69.

17. Chowdhry, V.; Westheimer, F. H.; Annu. Rev. Biochem. 1979, 48, 293.

18. Bayley, H.; Photogenerated Reagents in Biochemistry and Molecular Biology, Elsevier: New York, 1983.

19. Siegel, F-S. M.; Porto, F.; Frost, P.; Arch. Biochem. Biophys. 1959, $81,330$.

20. Siegel, S. M. Frost, P.; Proc. Natl. Acad. Sci. U. S. A. 1959, 46, 1379.

21. Blanok, F. C. Handbook of Food and Agriculture; Ed. Reinhold Publishing Co: New York, 1955; p. 243, 253, 286, 592. 
22. Lundberg, W. O.; Autoxidation and Antioxidants; vol. I, Interscience Publishers: New York, 1962, 1069.

23. Siegel, S. M.; F. Porto; Frost, P.; Physiol. Plant. 1959, 14, 727.

24. Edgar, K. J.; Fallng, S. N.; J. Org. Chem. 1990, 55, 5287.

25. Liu, Z.; Larock, R. C.; Org. Lett. 2004, 6, 3739.

26. Gershon, H.; McNeil, W.; Grefig, A. T.; J. Org. Chem. 1969, $34,3268$.

27. Garden, S. J.; Torres, J. C.; Melo, S.C.S.; Lima, A. S.; Pinto, A. C.; Lima, L. S.; Tetrahedron Lett. 2001, 42, 2089.

28. Markovich, K. M.; Tantishaiyakul, V.; Hamada, A.; Miller, D. D.; Romstedt, K. J.; Shin, G.; Shams, Y.; Fraudorfer, P. F.; Doyle, K.; Feller, D. R.; J. Org. Chem. 1992, 466.

29. Barluenga, J.; Golzávez, J. M.; Gárcia-Martín, M. A.; Campos, P. J.; Asensio, G.; J. Org. Chem. 1993, 58, 2058.

30. Mukaiyama, T.; Kitagawa, H.; Matsuo, J. I.; Tetrahedron Lett. 2000, 41, 9383.

31. Branytska, O.V; Neumann, R.; J. Org. Chem. 2003, 68, 9510.

32. Brunel, Y.; Rousseav, G.; Tetrahedron Lett. 1995, 36, 8217.

33. Adimurthy, S.; Ramachandraiah, G.; Ghosh, P. K.; Bedekar, A.V.; Tetrahedron Lett. 2003, 44, 5099.

34. Das, B.; Krishnaiah, M.; Venkateswarlu, K.; Reddy, V. S.; Tetrahedron Lett. 2007, 48, 81.

35. Ribeiro, R. da S.; Esteves, P. M.; de Mattos, M. C S.; J. Braz. Chem. Soc. 2008, 19, 1239.

36. Giza, C. A.; Hinmam, R. L.; J. Og .Chem. 1964, 29, 1453.

37. Southwick, P. L.; Christman, D. R.; J. Am .Chem. Soc. 1952, $74,1886$.

38. Rice, R.V.; Heights, H.; US pat. 2,290,710, 1942.

39. Perez, A. L.; Lamoureux, G.; Herrera, A.; Synth. Commun. 2004, 34, 3389.

40. Adimurthy, S.; Ramachandraiah, G.; Ghosh, P. K.; Bedekar, A. V.; Tetrahedron Lett. 2003, 44, 5099.
41. Lista, L.; Pezzella, A.; Napolitano, A.; d'Ischia , M.; Tetrahedron 2008, 64, 234.

42. Tadashi Kometani T.; Watt, D. S.; J. Org. Chem. 1985, 50, 5384.

43. Lenderink, L.; Duppen, K.; Everdij, F. P. X.; Mavri, J.; Torre, R.; Wiersma, D. A.; J. Phys. Chem. 1996, 100, 7822.

44. Cheng, P. Y.; Zhong, D.; Zewail, A. H.; J. Phys. Chem. 1996, 105, 6216.

45. Zhong, D.; Zewail, A. H.; Proc. Natl. Acad. Sci. U. S. A. 1999, 96, 2602.

46. Zhong, D.; Bernhardt, T. H.; Zewail, A. H.; J. Phys. Chem. A 1999, 103, 10093.

47. Ananthavel, S. P. ; Monoharan, M.; Chem. Phys. 2001, $269,49$.

48. Kusama, H.;Sugihara, H.; J. Photochem. Photobiol., A 2006, $181,268$.

49. Lu, Y. X.; Zou, J. W.; Wang, Y. H.; Yu, O. S.; J. Mol. Struct. 2006, 776, 83.

50. Huang, Q.; Wang, Z.; Chu, Q.; Zhu, S.; J. Inclusion Phenom. Macrocyclic Chem. 2006, 54, 177.

51. Lucassen; A. C. B.; Karton, A.; Leitus, G.; Shimon, L. J. W.; Martin, J. M. L.; van der Boom, M. E.; Cryst. Growth Des. 2007, $7,386$.

52. Tang; L. T; Wei, Y.; Wang, Y.; Hu, S. W.; Liu, X. O.; Chu, T. W.; Wang, X. Y. J. Mol. Struct. 2004, 686, 25.

53. Eshghi1, H.; Tayyari, S. F.; Sanchuli1, E.; Monatsh. Chem. 2004, 135, 1101.

54. Oetting, T.; Klapötke, T. M.; Polyhedron 1989, 24, 2911.

55. Vasil'ev, A. A.; Engman, L.; J. Org. Chem. 1998, 63, 3911.

56. Potts, K. T.; J. Chem. Soc. 1953, 53, 3711.

57. Hodgen, H. H.; Moore, F. H.; J. Chem. Soc. 1925, 2260.

58. Varma, P. S.; Yashoda, K. M.; J. Indian Chem. Soc. 1939, 477.

59. Thorn, G. D.; Purves, C. B.; Can. J. Chem. 1954, 32, 373.

Received: December 17, 2008

Web Release Date: September 25, 2009 